\title{
José Luis Gómez-Skarmeta (1966-2020)
}

\author{
On 16 September 2020, when the news of José Luis Gómez-Skarmeta's untimely passing broke, the scientific \\ community was left in dismay.
}

T: witter became engulfed with words of support for José Luis's family and friends, and the telephones of his global network of collaborators did not stop ringing for days. José Luis was the embodiment of collaborative science, a living scientific hub who influenced the lives of so many of us in profound ways. The field of developmental and evolutionary genomics had just lost a foundational figure, a mentor and one of its most prolific scientists.

José Luis Gómez-Skarmeta was born in 1966, in Santiago, Chile, where he lived for the first 7 years of his life. His childhood was marked by an impressive number of intercontinental moves: before the age of 18 , he had already lived in Puerto Rico, Spain, Chile and Colombia. He studied chemistry and biochemistry at the University of Murcia in Spain and, after a brief internship at Stanford University in the United States, he went on to conduct his $\mathrm{PhD}$ research at the Centro de Biología Molecular Severo Ochoa at the Universidad Autónoma de Madrid in Spain. He then moved back to Chile and became an assistant professor at the University of Chile, a position he held for two and a half years before joining the Consejo Superior de Investigaciones Científicas in Spain. In 2003, he played a key role in founding the Andalusian Center for Developmental Biology (CABD, Spain), where he led the functional genomics laboratory until his premature passing. José Luis's multicultural heritage may have helped him bond and form long-lasting ties with researchers all over the world. He traveled frequently, and, wherever he went, he was well known for his charismatic personality, his sense of humor, and his unparalleled energy and passion that he poured into every aspect of his scientific work. Whether running a summer course at the Marine Biological Laboratory in Woods Hole, doing a sabbatical in Perth, or organizing a zebrafish course in Bangkok, he was fully committed.

His scientific career vastly grew from its already spectacular beginnings but was truncated at its apex. José Luis made key contributions to the fields of development, genome regulation and evolutionary biology. These contributions started with his work on the iroquois genes in flies in the laboratory of Juan Modolell, where

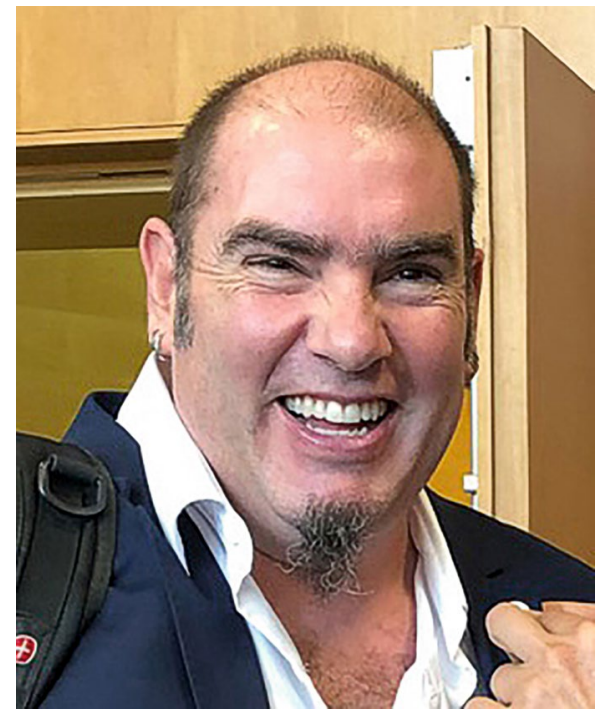

Credit: Juan Lerma Gómez

he discovered and named araucan and caupolican, two of the three genes in the iroquois ( $I r x$ ) cluster in Drosophila. The special syntenic and three-dimensional (3D) organization of this gene cluster, as well its intricate regulation and evolution, contained all the ingredients that determined José Luis's future groundbreaking discoveries. In his first projects as an independent researcher, he focused on elucidating the developmental roles of the orthologs of the Irx genes in vertebrates. He and Elisa de la Calle-Mustienes, his wife and lifelong collaborator, together dissected the principles of the transcriptional regulation of these gene clusters, and this led José Luis to one of his many pet scientific passions: bringing regulatory elements to light by using zebrafish transgenesis, a technique whose development he greatly contributed to over the years. His subsequent work on the Irx clusters helped establish the importance of 3D genome organization in their regulation, when this currently hot topic was still in its infancy. Over the next few years, he shifted his focus from Ir $x$ to other gene clusters and then to the entire genome, thus leading him to yet another of his pet scientific passions: browsing 'omics' data in the UCSC Genome Browser. Around that time, his interest in evolution began to solidify and expand, with highlights including the discovery of the most deeply conserved regulatory elements in animals and the origin of the Irx clusters themselves. This interest in studying basic principles of genomic regulatory evolution continued to grow until the end of his career. Although his contributions to understanding disease (for example, obesity and diabetes) were outstanding, his latest projects, in his unique and creative way, examined the origin and evolution of vertebrates. His work characterized the origin of the special 3D Hox-cluster organization in the chordate lineage, the conservation of enhancer regulation during the phylotypic period and the origin of paired fins, to name a few. These landmark studies prompted his laboratory to increasingly combine advanced genomics and functional approaches with the use of unconventional model organisms, such as amphioxi, skates or cavefish. Although these efforts resulted in several prematurely truncated projects, nonetheless, we are confident that these studies will take shape soon, given that José Luis and his group worked tirelessly on them until the very last moment.

His seminal scientific contributions granted him increasing recognition in recent years. In 2017, he was awarded a prestigious European Research Council advanced grant and a Carmen and Severo Ochoa Award, the highest Spanish molecular biology accolade, and he was elected as a European Molecular Biology Organization member in 2019. Moreover, his success transcended the individual level when his department was recognized with the Spanish seal of excellence, Maria de Maeztu-an achievement that he was particularly proud of.

However, the scientific community will remember him not only for these awards but also for his passion for science, energetic personality and collaborative philosophy, which he incorporated into a unique way of doing research. Over the course of his career, he published 117 scientific articles with 564 coauthors. As anyone who worked with José Luis knows, most of these collaborators probably enjoyed (at least) a beer with him, over which he passionately discussed collaborations and science. This attitude was just a reflection of his restless working style. The first thing he would do in the 
morning upon arriving at work was check the fluorescence in all ongoing transgenic zebrafish experiments in his laboratory. In every encounter or chat, he would open the UCSC Genome Browser to highlight some new amazing data that his team had just generated. He perhaps disliked only writing articles. Still, he would famously lock himself in his office and listen to loud heavy metal while he battled with the words that would lead to another T-shirt trophy. His restless passion persisted until his very last days, and he never stopped doing what he always loved. One anecdote says it all: he submitted his last manuscripts just a week before he passed.

Still, reducing José Luis's personality to just his science would be a major oversimplification. Dozens of people could spend days telling their personal anecdotes about José Luis (also known as JL, Jose, Skarmeta or Pepelu). Nevertheless, if we had to pick a single personality trait that defined him best, without hesitation we would choose his generosity. José Luis was generous in all possible ways, including his resources, his time and his advice. His passion for helping others deliver their best science and for mentoring young scientists was unmatched. We can personally attest to numerous occasions when his help and support were critical in advancing scientific careers. For instance, in 2010, when one of us (O.B.) started working at the CABD, the reviewer comments came in for an article whose publication was long overdue and necessary for the completion of a $\mathrm{PhD}$ thesis. The comments included a request to generate transgenic frogs. When José Luis saw this request, he did not waste a second. He ran to his office and, from among a seemingly disorganized pile of articles and old notebooks, he dug up the plasmid maps and localized all the components and enzymes needed to generate the transgenic construct. Over the next few weeks, José Luis personally injected hundreds, if not thousands, of frog embryos to collect enough material. This amount of help and level of involvement by a senior scientist seemed exceptional to O.B. The success of this frog experiment proved key in the acceptance of the article and ultimately the approval of the $\mathrm{PhD}$ thesis. We frequently reminisce about this experience as well as the multitude of other positive interactions we had with José Luis, realizing how his influence has shaped us-and many other colleagues-and helped us become better scientists and mentors.
José Luis will be greatly missed as a friend, an advisor and a colleague for many in Spain and worldwide. Fortunately, his rich legacy remains not only through his scientific publications and those yet to come, but also through myriad young (and not so young) researchers whom he trained and helped establish. José Luis is survived by Elisa, his partner in the laboratory and life, and their two children, Claudia and Pablo.

Ozren Bogdanovic (D) $1,2 \bowtie$ and Manuel Irimia (iD) 3,4,5凶

${ }^{1}$ Garvan Institute of Medical Research, Sydney, New South Wales, Australia. ${ }^{2}$ School of Biotechnology and Biomolecular Sciences, University of New South Wales, Sydney, New South Wales, Australia. ${ }^{3}$ Centre for Genomic Regulation (CRG), Barcelona Institute of Science and Technology, Barcelona, Spain. ${ }^{4}$ Universitat Pompeu Fabra (UPF), Barcelona, Spain. ${ }^{5}$ ICREA, Barcelona, Spain.

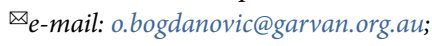
mirimia@gmail.com

Published online: 4 November 2020 https://doi.org/10.1038/s41588-020-00743-5

Acknowledgements

The authors thank the family, friends and collaborators of José Luis Gómez-Skarmeta for help with the preparation of this article. 